\title{
Does Job Satisfaction Mediate the Effect of Procedural Justice and Distributive Justice on Organizational Commitment?: Case Study of Education Institution
}

\author{
Fatmah Bagis \\ Muhammadiyah Purwokerto University \\ fatmahbagis@ump.ac.id
}

\begin{abstract}
This study explains about organizational justice including procedural justice and distributive justice and its effect on organizational commitment, where job satisfaction is used as a mediation variable. The method used in this study is case study on employees of education institution in Purwokerto. Questionnaires were administered to 74 employees from the management level to the staff level as the respondents. Data analysis techniques used are the analysis of PLS (Partial Least Square) using SmartPLS 3.0. The results showed that Procedural Justice, Distributive Justice has significant effect on Job Satisfaction, and Job Satisfaction has significant effect on Organizational Commitment. It also proved that job satisfaction could mediate the relationship between procedural justice and organizational commitment but it cannot mediate the relationship between distributive justice and organizational commitment.
\end{abstract}

Keywords: procedural justice, distributive justice, job satisfaction, and organizational commitment

\section{INTRODUCTION}

Today competition between educational organizations, in this case university, demanding that each university can provide quality service to the largescale community. University is required to work optimally in order to bring hope to the presence of highquality educational services that is easily accessible by the public. To improve the quality of the learning process and progress within the university organization itself, it needs an increase in lecturer professionalism. In other words, the lecturers not only have to improve his knowledge but also to have a strong commitment in his university organization.

Organizational justice as a concept of balance in treating employees is expected to be applied by organization with aims of triggering the growth of a sense of commitment in the employee. [1]stated that organizational commitment refers to an employee's loyalty to the organization and involvement in the organization. [2]argue that organizational commitment is a bond to the whole organization and not just to the job, work group, or belief in the importance of work itself.

Many researchers have demonstrated the connection between distributive and procedural justice to organizational commitment ([3], [4], [5], [6]). However, they paid little attention on validating the similar connection within the context of Indonesian university organization. Understanding and promoting commitment to employees in the organization is essential to the efficiency and effectiveness of the organization [7]. Employees who are treated unfairly will show negative behavior towards the organization in the fo, rm of low commitment and desire to leave the organization. Meanwhile, the willingness of employees to contribute and commit to the workplace is strongly influenced by the organization's ability to meet the goal of employee expectations[8].

Colquitt [9] stated that organizational justice can be defined as a combination of the fairness of the procedures used by leaders to determine outcome distributions or allocation (procedural justice), and the fairness of outcome distributions or allocations (distributive justice). Those two types of justice are used because it link to outcome of work which can have impact on organizational commitment. Therefore, this study will try to test the connection between procedural justice and distributive justice or the basic justice obtained by employees based on the wages they get and the work they do, to employee organizational commitment.

Distributive justice exists when employees base their evaluations of supervisor partially on the extent to which they perceive organizational outcomes[10], such as salary and promotion decisions, as being distributed evenhandedly across the organization (i.e., such decision is not based on individual characteristics or "who you know"). Typically, distributive justice exists when the expectations for outcomes and actual outcomes are equal[11]. In general, people expect outcomes to be commensurate with outputs (e.g., experience, ability, and effort). 
Procedural justice, on the other hand, focuses on the decision process taken to determine the outcome of work that is seen as reasonable [12]. It refers to fairness in the means by which distributions or decisions are made [13]. For most employees, procedural justice reflects the perceived fairness of the process by which distributive outcomes are determined such as the way by which pay, rewards, evaluation, and/or opportunity to develop themselves are decided.

The other objectives in this study are to test the effect of job satisfaction to organizational commitment, and how job satisfaction mediate the relationship between procedural justice and distributive justice to organizational commitment. Job satisfaction, in general, is the positive or negative attitudes towards job [14]. Some previous researches showed that job satisfaction has a positive and significant relationship ([15], [16], [17]). Karami [18] found that supervisors required to definitely develop their company's job satisfaction for workers to obtain an advanced level of organizational commitment. [19]also analyzed the effects of job satisfaction on orgaizational commitment among 280 Iranian employess in service firm and the findings proved that job satisfaction has positive and significant effect on organizational commitment.

According to Poggi [20], job satisfaction is a determinative of organizational commitment. The main difference between organizational commitment and job satisfaction is that, while organizational commitment can be defined as the emotional responses which an employee has been towards his organization, job satisfaction is the responses that an employee has been towards any job. It is considered that these two variables are highly interrelated. In other words, when an employee has positive feelings towards the organization, its values and objectives, usually he is satisfied with the job he has in the organization.

In study by Jena [21], indicated that participant who is satisfied with pay, promotion, supervision, relationship with co-workers, nature of the work, and communication (organizational and job-specific) seem to feel more emotionally attached and involved with their respective organization. It can be said that employees perceived on distributive and procedural justice will have high job satisfaction and then commit to organization voluntarily.

Based on the description that is stated in introduction and research objective, the proposed hypotheses are:

H1: Procedural justice has positive effect on job satisfaction.

$\mathrm{H} 2$ : Distributive justice has positive effect on job satisfaction.

H3: Job satisfaction has positive effect on organizational commitment.

H4a: Job satisfaction mediates the relationship between procedural justice and organizational commitment.

H4b: Job satisfaction mediates the relationship between distributive justice and organizational commitment.

\section{METHOD}

This study used quantitative approach. Survey method is used in this study using self-report questionnaire which is personally administered to employees at an educational institution in Purwokerto. An explanatory cover letters and questionnaires were acquired from 74 employees from the management level to the staff level. Data analysis used in this study is Partial least squares (PLS) analysis.

\section{PROCEDURAL JUSTICE}

Procedural fairness refers to the fairness of all aspects of the organization's procedures that are used by the superior to evaluate the subordinate's performance, to communicate performance feedback and to determine the subordinate's rewards such as promotion and pay increases [25]. This variable is measured using six items instrument developed by [26].

\section{DISTRIBUTIVE JUSTICE}

Distributive justice is defined as the fairness of outcome distributions or allocation [9]. This variable is measured using six items instrument developed by [26].

\section{JOB SATISFACTION}

According to [27], job satisfaction is a pleasurable or positive emotional state resulting from the appraisal of one's job or job experiences. Job satisfaction was measured using nineteen items developed by [28].

\section{ORGANIZATIONAL COMMITMENT}

Organizational commitment is the employee's level of involvement and identification with the organization in which he or she works [29]. Measuring instrument used for this variable is a questionnaire developed by [29].

\section{RESULT}

\section{Hypothesis Testing}

The hypothesis testing is done by using 95\% $(\alpha=$ $0,05)$ significance level. From the result of Partial Least Square analysis, it can be seen that distributive justice has significant effect on job satisfaction and the first hypothesis which states that distributive justice had significant effect on job satisfaction, was supported. The result of generates the value of factor loading at 0,298 which means that $29,8 \%$ of job satisfaction could be explained by distributive justice.

The result of Partial Least Square analysis also showed that procedural justice has significant effect on job satisfaction and second hypothesis which states that procedural justice had significant effect on job satisfaction, was supported. The result of generates the 
value of factor loading at 0,520 which means that 52,0\% of job satisfaction could be explained by procedural justice.

From the result of Partial Least Square analysis, it can be seen that job satisfaction has significant effect on organizational commitment and the third hypothesis which states that job satisfaction had significant effect on organizational commitment, was supported. The result of generates the value of factor loading at 0,610 which means that $61,0 \%$ of organizational commitment could be explained by job satisfaction.

\section{Mediation Effect}

This study used Sobel test to tell whether a mediator variable significantly carries the influence of an independent variable to a dependent variable. From the result of Sobel Test showed in Table 1, it can be concluded that job satisfaction could mediate the relationship between procedural justice and organizational commitment but it cannot mediate the relationship between distributive justice and organizational commitment.

Table 1. Result of Sobel Test

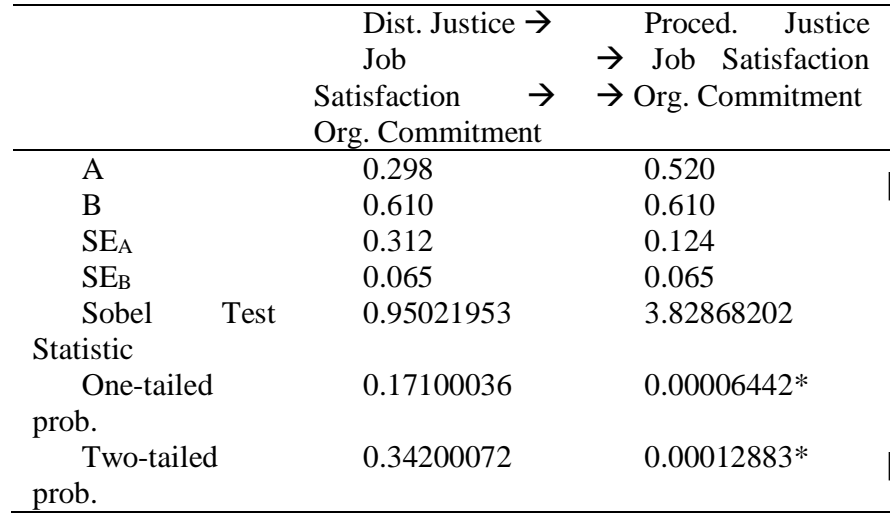

\section{CONCLUSION}

Procedural justice and distributive justice, both have significant effect on Job Satisfaction of employees in educational institution. The better the university management enforces policies relating to procedural and distributive justice, the more satisfied the employee will be at the university.

Job Satisfaction has a significant influence on organizational commitment of employees of educational institution. It shows that when employees feel more satisfied then they will have higher commitment to the university. It also can be concluded that that job satisfaction could mediate the relationship between procedural justice and organizational commitment but it cannot mediate the relationship between distributive justice and organizational commitment.

It is expected that further research will develop other variables such as work discipline, leadership style and organizational culture in educational institutions that will be compared with organizational commitment.

\section{REFERENCES}

[1] L.M.Shore and H.J.Martin,"Job Satisfaction and Organizational Commitment in Relations on Work Performance and Turnover Intentions," Hum. Relations, vol. 42, no. 7, pp. 625-638, 1989.

[2] E.G.Lambert,N. L. Hogan, and S M.Barton,"Satisfied Correctional Staff: a Review of the: literature on the Correlates of Correctional Staff Job Satisfaction,"vol. 29, no. 2, pp. 115-143, 2002.

[3] K.Demir,"The Effect of Organizational Justice and Perceived Organizational Support on Organizational Citizenship Behaviors: the Mediating Role of Organizational Identification,"Eurasian J.Educ.Res., no.60, pp. 131-148, 2015.

[4] Q.Iqbal and B.Ahmad,"Organizational Justice, Trust and Organizational Commitment in Banking Sector of Pakistan," J. Appl. Econ. Bus., vol. 4, no. 1, pp. 26-43, 2016.

[5] G.Murtaza, I. Shad, K. Shahzad, M. K. Shah, and N.A. Khan,"Impact of Distributive and Procedural Justice on Employees Commitment: a Case of Public Sector Organization of Pakistan,"Eur.J.Econ.Financ. Adm. Sci. Issue, vol. 29, pp. 73-80,2011.

[6] M.C.-T.Tsai,“An Empirical Study of the Conceptualization of Overall Organizational Justice and Its Relationship with Psychological Empowerment , Organizational Commitment and Turnover Intention in Higher Education Markus Chia-Han Tsai A dissertation submitted in par," University of Washington, 2012.

[7] M.L.Griffin and J.R.Hepburn, "Side-Bets and Reciprocity as Determinants of Organizational Commitment among Correctional Officers," J.Crim. Justice, vol. 33, pp.611-625, 2005.

[8] D.Mary, H.Mary, and R.A.Wijaya, "The Effect of Procedural Justice, Distributive Justice, Job Satisfaction and Organizational Commitment to Organizational Citizenship Behavior in Pariaman, West Sumatera, Indonesia," J. Bus.Econ., vol. 1, no. 1, pp. 16-29, 2016.

[9] J.A.Colquitt, "On the Dimensionality of Organizational Justice: a Construct Validation of a Measure," J. Appl. Psychol., vol. 86, no. 3, pp. 386400, 2001.

[10] J.Nix and S.E.Wolfe, "Journal of Criminal Justice Sensitivity to the Ferguson Effect: the Role of Managerial Organizational Justice," J.Crim. Justice, vol. 47, pp. 12-20, 2016.

[11] J.Clay-Warner, K.A.Hegtvedt, and P.Roman, "Procedural Justice, Distributive Justice: How Experiences with Downsizing Condition Their Impact on Organizational Commitment," Socia; Psychol. Q., vol. 68, no. 1, pp. 89-102, 2005.

[12] M.Sholihin, R.Pike, M.Mangena, and J.Li, "GoalSetting Participation and Goal Commitment: 
Examining the Mediating Roles of Procedural Fairness and Interpersonal Trust in a UK Fi nancial Services Organisation," Br. Account. Rev., vol. 43, no. 2, pp. 135-146, 2011.

[13] K.A.Hegtvedt and B.Markovsky, "Justice and Injustice," in Sociological Perspectives on Social Psychology, no. January, K.Cook, G.A.Fine, and J. House, Eds. Boston: Allyn and Bacon, 1995, pp. 257-280.

[14] E.B. Bayarçelik and M.A.Findikli, "The Mediating Effect of Job Satisfaction on the Relation Between Organizational Justice Perception and Intention to Leave," in Procedia - Social and Behavioral Sciences, 2016, vol. 235, no.October, pp. 403-411.

[15] D.W. Ariani, "Relationship personality, job satisfaction, organizational commitment and organizational citizenship behavior of service industries in Indonesia," Res. J. Bus. Manag., vol. 8, no. 3, pp. 262-283, 2014.

[16] P.Lok and J.Crawford, "Antecedents of Organizational Commitment and the Mediating Role of Job Satisfaction," J.Manag. Psychol., vol. 16, no. 8, pp. 594-613, 2001.

[17] V.Tarigan and D.W.Ariani, "Empirical Study Relations Job Satisfaction, Organizational Commitment, and Turnover Intention," $A d v$. Manag. Appl. Econ., vol. 5, no. 2, pp. 21-42, 2015.

[18] M. Karami, S.Khan, H. M. Ishaq, and M. Siddique, "Empirical Evidence of Job Satisfaction and Organizational Commitments," Sci. Int, vol. 26, no. 5, pp. 2395-2400, 2014.
[19] J.Eslami and D.Gharakhani,"Organizational Commitment and Job Satisfaction," J.Sci. Technol., vol. 2, no. 2, pp. 85-91, 2012.

[20] A.Poggi,"Job satisfaction, working conditions and aspirations," J. Econ. Psychol., vol. 31, no. 6, pp. 936-949, 2010.

[21] R.K. Jena,"The Effect of Job Satisfaction on Organisational Commitment among Shift Workers: A Field Study of Ferro-alloy Industries," AsiaPacific J. Manag. Res. Innov., vol. 10, no. 2, pp. 109-118, 2014.

[25] R. Folger and M.A. Konovsky, "Effects of Procedural and Distributive Justice on Reaction to Pay Raise Decisions.pdf," Acad.Manag. J., vol. 32, no. 1, pp. 115-130, 1989.

[26] T. L.-P. Tang and L. J. Sarsfield-Baldwin, "Distributive and Procedural Justice as Related to Satisfaction and Commitment," 1996, pp. 1-25.

[27] E.A. Locke, "What is Job Satisfaction?," Organ. Behav. Hum. Perform., vol. 4, no. 4, pp. 309-336, 1969.

[28] A.H.Brayfield and H.F. Rothe, "An Index of Job Satisfaction," J. Appl. Psychol., vol. 35, no. 5, pp. 307-311, 1951.

[29] C.O'Reilly and J.Chatman ,'Organizational Commitment and Psychological Attachment. The Effects of Compliance, Identification, and Internalization on Prosocial Behavior," J.Appl. Psychol., vol. 71, no. 3, pp. 492-499, 1986. 